\title{
Growth, cellular differentiation and virulence factor expression by Proteus mirabilis in vitro and in vivo
}

\author{
P. ZUNINO, C. PICCINI and C. LEGNANI-FAJARDO \\ División Microbiología, Instituto de Investigaciones Biológicas Clemente Estable, Avda. Italia 3318, CP11600, \\ Montevideo, Uruguay
}

\begin{abstract}
A uropathogenic strain of Proteus mirabilis was grown in vitro in human and mouse urine and brain-heart infusion broth (BHIB) and in vivo in subcutaneous open chambers (SOC) in mice, intraperitoneal diffusion chambers (IPC) in rats and by ascending urinary tract infection in mice in order to compare growth pattern, cellular differentiation and expression of virulence factors. Although the growth rate was slower in vivo than in vitro, the extent of growth was similar after $24 \mathrm{~h}$. $P$. mirabilis differentiated into filamentous swarmer cells in all in-vitro culture conditions, but no filamentous cells were observed in either of the in-vivo chamber models. Transurethrally infected mice showed a rapid release or loss of filamentous cells and these could not be seen in kidney or bladder homogenates 7 days after infection. Bacteria showed increasing haemagglutination titres for fresh and tanned red blood cells after subculturing in BHIB, but bacteria grown in vivo did not show haemagglutination. An increasing resistance to normal serum was found when bacteria were grown in vivo. Significant haemolytic activity was detected with bacteria grown in BHIB and IPC, but almost no activity was found when bacteria had grown in urine. These findings improve the understanding of the role of $P$. mirabilis uropathogenic virulence factors in vivo.
\end{abstract}

\section{Introduction}

Proteus mirabilis is a common cause of urinary tract infection (UTI) in catheterised patients and those with urinary tract abnormalities. It often infects the upper urinary tract where it can lead to acute pyelonephritis, bladder or renal stones, fever and bacteraemia [1-3].

Several potential virulence factors have been suggested for $P$ mirabilis. These include urease production [3], cell invasiveness [4,5], cleavage of IgG and IgA by a proteolytic enzyme [6], outer-membrane proteins [7], haemolysin production [8], adhesion to the uro-epithelium $[9,10]$, swarming motility by fiagella $[11,12]$ and resistance to normal serum [13].

The most commonly used models for studying the role of some of these factors in virulence have been the ascending or intravenous UTI models in mice $[14,15]$. However, very few descriptions of how $P$. mirabilis expresses its virulence factors in vivo have been

Received 2 June 1998; revised version accepted 2 Sept. 1998.

Corresponding author: Dr P. Zunino. reported, and studies of appropriate bacterial-host interactions have not been exhaustive.

Subcutaneous open chamber (SOC) and intraperitoneal diffusion chamber (IPC) models have been used to study different aspects of pathogenicity in Neisseria gonorrhoeae [16], Haemophilus ducreyi [17], Borrelia burgdorferi [18], Streptococcus suis [19], Pseudomonas aeruginosa [20] and Aeromonas salmonicida [21]. Although these models lack a mucosal surface and, therefore, are not suitable for adhesion or invasion studies, they enable the analysis of different bacterial characteristics in vivo. The SOC model allows studies on infectivity and survival in the presence of inflammatory and immune responses [16]. The IPC model has proved to be a valuable tool in studying changes induced in bacterial cell composition in vivo [22], making possible the recovery of high numbers of pure bacteria grown in vivo and the analysis of expression of diverse virulence factors [19].

These models had not been used previously to study $P$. mirabilis in vivo. Different virulence factors were selected for the present study. Some, such as MR/P and $M R / K$ fimbriae $[9,23]$ and swarmer cell differentiation [12], are thought to be important in the 
development of $P$. mirabilis urinary infections, whereas others such as haemolysin [24] or resistance to normal serum [13] have a role that is difficult to evaluate in the commonly used mouse models.

In this study, the growth patterns and expression of these $P$. mirabilis virulence factors were compared when a clinical isolate was grown in brain-heart infusion broth (BHIB), human and mouse urine, SOC in mice and IPC in rats. Ascending urinary tract infection in mice was analysed to complement cellular differentiation studies in vivo.

\section{Materials and methods}

\section{Bacterial strain}

A clinical isolate of $P$. mirabilis, Pr 990 [25] was used in all experiments. Swimming motility was tested by inoculation into semi-solid nutrient agar (NA) [26] and swarming motility on brain-heart infusion agar plates which had been dried at $37^{\circ} \mathrm{C}$ for $1 \mathrm{~h}$ [27]. In both cases, cultures were incubated overnight at $37^{\circ} \mathrm{C}$.

\section{Media and chemicals}

All media were from Difco Laboratories (Detroit, MI, USA) and all chemicals were reagent grade (Sigma).

\section{Urine}

Human urine from five healthy female donors was pooled. Mouse urine from 10 healthy female mice was collected after gentle massage of the abdomen and pooled. Both urine pools were filter sterilised immediately after collection and used fresh.

\section{Light and electron microscopy}

Smears of preparations for light microscopy were fixed in methanol for $5 \mathrm{~min}$ and stained with methylene blue $0.8 \%$. The ratio between long filamentous swarmer cells and short vegetative cells was established after counting all cells from 40 randomly chosen fields. Quantification of the different cell types was done in duplicate preparations. The same microscope conditions were maintained for all observations, which were performed by the same worker. Cells were considered as filamentous when they were $\geqslant 10 \mu \mathrm{m}$ long [28], $c$. five times longer than normal vegetative bacteria.

For electron microscopy, one drop of a bacterial suspension at an appropriate concentration was placed on a formvar-coated grid, fixed with paraformaldehyde $10 \%$, washed with double-distilled water and negatively stained with uranyl acetate $1 \%$. The specimens were then examined in a Jeol 100CX II electron microscope operating at $60 \mathrm{kV}$.

\section{Animals}

Female outbred mice weighing $20-25 \mathrm{~g}$ and outbred rats weighing 220-250 g from the breeding facilities at IIBCE, Montevideo, were used and provided with food pellets and tap water ad libitum. All animal experiments were conducted in accordance with procedures authorised by IIBCE (Montevideo, Uruguay).

\section{Bacterial growth in vitro}

P. mirabilis Pr 990 cells from an overnight culture on $\mathrm{NA}$ at $37^{\circ} \mathrm{C}$ were suspended in phosphate-buffered saline (PBS), pH 7.2, at $6 \times 10^{8} \mathrm{cfu} / \mathrm{ml}$. Then $100 \mu \mathrm{l}$ of this suspension were added into $9.9 \mathrm{ml}$ of BHIB or human or mouse urine and incubated statically at $37^{\circ} \mathrm{C}$ for $24 \mathrm{~h}$. Samples were taken at different times and cells were counted after overnight culture on NA (agar $2 \%$ ) incubated at $37^{\circ} \mathrm{C}$.

\section{Bacterial growth in vivo}

Subcutaneous open chambers (SOC) in mice. Sterile silicone-rubber tubes $(10 \mathrm{~mm}$ long and $8 \mathrm{~mm}$ outside diameter) were introduced subcutaneously at both sides of the back of four anaesthetised mice [17]. The inflammatory response was evaluated by periodic extraction of internal fluid and inflammatory cells were counted in a Neubauer chamber. When the counts of inflammatory cells were $<10^{5} / \mathrm{ml}$, (c. 45 days after the implant), $100 \mu \mathrm{l}$ of a suspension in PBS of bacteria from an overnight culture on NA at $6 \times 10^{5} \mathrm{cfu} / \mathrm{ml}$ were inoculated into one chamber after extraction of the fluid. Plate counts and light microscopy preparations were made on samples taken at $4,8,12$ and $24 \mathrm{~h}$ and 2, 5, 12, 19 and 26 days after inoculation. Mouse blood obtained by cardiac puncture was cultured on appropriate media to test for spread of bacteria from the inoculated chambers.

Intraperitoneal diffusion chambers (IPC) in rats. Diffusion chambers [21] were made from $1.5-\mathrm{ml}$ conical micro-centrifuge tubes and sealed with a $0.45-\mu \mathrm{m}$ pore nitrocellulose membrane which was attached after heating the edge of the tube. The chambers were autoclaved, and $1 \mathrm{ml}$ of a PBS suspension $(6 \times$ $10^{5} \mathrm{cfu} / \mathrm{ml}$ ) of bacteria grown on NA was inoculated through a hole made in the side of the tube with a heated needle. The hole was sealed by heat from a glass rod. Two chambers were introduced through a 1$\mathrm{cm}$ longitudinal incision into the peritoneal cavity of rats anaesthetised previously by intramuscular injection of ketamine hydrochloride $(88 \mathrm{mg} / \mathrm{kg}$ ) and xylazine $(4 \mathrm{mg} / \mathrm{kg}$ ). The abdomen was sutured with vicryl 000 and the skin with nylon 000 [19]. After 4, 8, 12 and $24 \mathrm{~h}$ and 2 and 5 days the rats were killed (three rats per sampling point), and the chambers were removed, washed carefully with sterile saline and internal fluid was recovered with a sterile syringe. 


\section{Ascending infection in mice}

The ascending UTI mouse model of Hagberg et al. was used [14]. Mice with bacteria present in urine cultured $24 \mathrm{~h}$ before challenge were not used. For the study of the persistence of filamentous and vegetative cells in the urinary tract, strain $\operatorname{Pr} 990$ was cultured in static aerobic conditions in BHIB at $30^{\circ} \mathrm{C}$ for 3 days. The culture was then centrifuged and the cells were suspended in PBS at $6 \times 10^{8} \mathrm{cfu} / \mathrm{ml}$. The ratio between filamentous and vegetative cells in the inoculum was 1:55. The mice were anaesthetised and their bladders were emptied by gentle abdominal massage. A soft polyethylene catheter (outer diameter $0.61 \mathrm{~mm}$ ) was inserted through the urethra and $0.05 \mathrm{ml}$ of the suspension $\left(3 \times 10^{7} \mathrm{cfu}\right)$ was slowly introduced into the bladder. For in-vivo urine smears from the trans-urethrally infected mice, bladder urine voided after gentle massage of the abdomen was recovered with a sterile loop. Mice were anaesthetised and killed 7 days after inoculation. Kidneys were removed aseptically and homogenised in a glass homogeniser in $1 \mathrm{ml}$ of PBS and smears for light microscopy were made.

\section{Haemagglutination assay}

Bacteria from in-vitro cultures and IPC were studied for their haemagglutinating activity with human and chicken erythrocytes $(\mathrm{rbc})$. Mannose-resistant/Proteuslike (MR/P) fimbriae were determined by mixing equal volumes $(0.05 \mathrm{ml})$ of two-fold dilutions of bacterial suspensions and a suspension of fresh rbc (3\%) in PBS in the presence of $50 \mathrm{mM}$ mannose at room temperature $\left(23^{\circ} \mathrm{C}\right)$. Mannose-resistant/Klebsiella-like (MR/K) fimbriae were assayed with tannic acid-treated human $\mathrm{rbc}$ [29]. Haemagglutination titres were defined as the highest dilution of bacterial suspension in which clumping of erythrocytes was observed.

The bacteria grown in vitro were prepared from a 24-h culture at $37^{\circ} \mathrm{C}$ on NA. The cells were suspended in PBS at $\mathrm{pH} 7.2$ to $3 \times 10^{8} \mathrm{cfu} / \mathrm{ml}$ and $250 \mu \mathrm{l}$ of this suspension were cultured in $5 \mathrm{ml}$ of BHIB at $30^{\circ} \mathrm{C}$ under static conditions and subcultured at 3-day intervals [30]. Cell pellets obtained after centrifugation of the first culture and the sixth subculture were suspended in PBS, pH 7.2, at $4 \times 10^{9} \mathrm{cfu} / \mathrm{ml}$ (determined by plate count on nutrient agar $2 \%$ ) and used in haemagglutination tests. The bacteria grown in vivo were from IPCs filled with $4 \times 10^{5} \mathrm{cfu} / \mathrm{ml}$ from a fifth subculture in BHIB. Three days after the chambers were implanted, they were removed, the inner fluid was centrifuged and the bacterial pellet was resuspended to $4 \times 10^{9} \mathrm{cfu} / \mathrm{ml}$ in PBS.

\section{Serum resistance assay}

The method used was a modification of that of others [16]. Briefly $50-\mu 1$ volumes of dilutions in PBS, $\mathrm{pH}$ 7.2 , of rat serum from fresh rat blood obtained by cardiac puncture were added to the round-bottomed wells of microtitration plates (Fisher Science). Bacterial suspensions at $10^{5} \mathrm{cfu} / \mathrm{ml}$ in $\mathrm{PBS}, \mathrm{pH} 7.2$, were prepared from an overnight culture in BHIB at $37^{\circ} \mathrm{C}$ and from an IPC after implantation for 2 days. Then, $50 \mu \mathrm{l}$ of each suspension were added to each well, including control wells that contained $50 \mu \mathrm{l}$ of PBS. After incubation in a moist chamber at $37^{\circ} \mathrm{C}$ for $50 \mathrm{~min}$ with shaking, $5 \mu \mathrm{l}$ from each well were subcultured in duplicate on NA (agar 2\%) plates and colonies were counted after incubation for $48 \mathrm{~h}$ at $37^{\circ} \mathrm{C}$. The percentage of cellular killing at different serum dilutions was expressed as:

\section{(cfu in control wells) - (cfu in test dilution)}

(cfu in control wells)

Statistical comparison was done by the $\chi^{2}$ test with Yates' corrections for sample size.

\section{Haemolysin assay}

The procedure described by Mobley and Chippendale [29] was used. For in-vitro assays, bacteria were grown overnight on NA at $37^{\circ} \mathrm{C}$ and suspended in BHIB or mouse or human urine at $1.0 \times 10^{5} \mathrm{cfu} / \mathrm{ml}$ and grown at $37^{\circ} \mathrm{C}$ with aeration. Samples were taken at different times and $0.1 \mathrm{ml}$ of two-fold dilutions of bacterial suspensions in PBS, pH 7.2, was mixed with $0.05 \mathrm{ml}$ of a $3 \%$ suspension of sheep rbc in PBS, $\mathrm{pH} 7.2$, and incubated at $37^{\circ} \mathrm{C}$ for $1 \mathrm{~h}$. The haemolytic titre was defined as the highest dilution in which no visible rbc pellet was observed.

For in-vivo assays, the procedures were the same, but the bacteria were those recovered from IPC.

\section{Results}

\section{Bacterial growth}

The kinetics of growth of $P$. mirabilis strain Pr 990 grown at $37^{\circ} \mathrm{C}$ in BHIB and human or mouse urine under static conditions was determined (Fig. 1). During exponential growth, doubling times were $29 \mathrm{~min}$ in BHIB, $45 \mathrm{~min}$ in human urine and $41 \mathrm{~min}$ in mouse urine. In urine cultures, after $10 \mathrm{~h}$, a visible salt precipitate was present and the number of viable bacteria showed a dramatic decrease from $10^{8}$ to $10^{3} \mathrm{cfu} / \mathrm{ml}$.

Bacterial growth in vivo was studied in IPC in rats and in SOC in mice (Fig. 1). IPC were introduced into the peritoneal cavity of rats, and bacterial growth was monitored by plate counts on NA at 4, 8, 12 and $24 \mathrm{~h}$. The viable count after $24 \mathrm{~h}$ was similar to that when bacteria grew in BHIB, although the growth rate during the first hours after chamber implantation was slower. Although the sampling could not be made as frequently as in BHIB or urine assays, the calculated doubling time between 4 and $12 \mathrm{~h}$ was $72 \mathrm{~min}$. For 


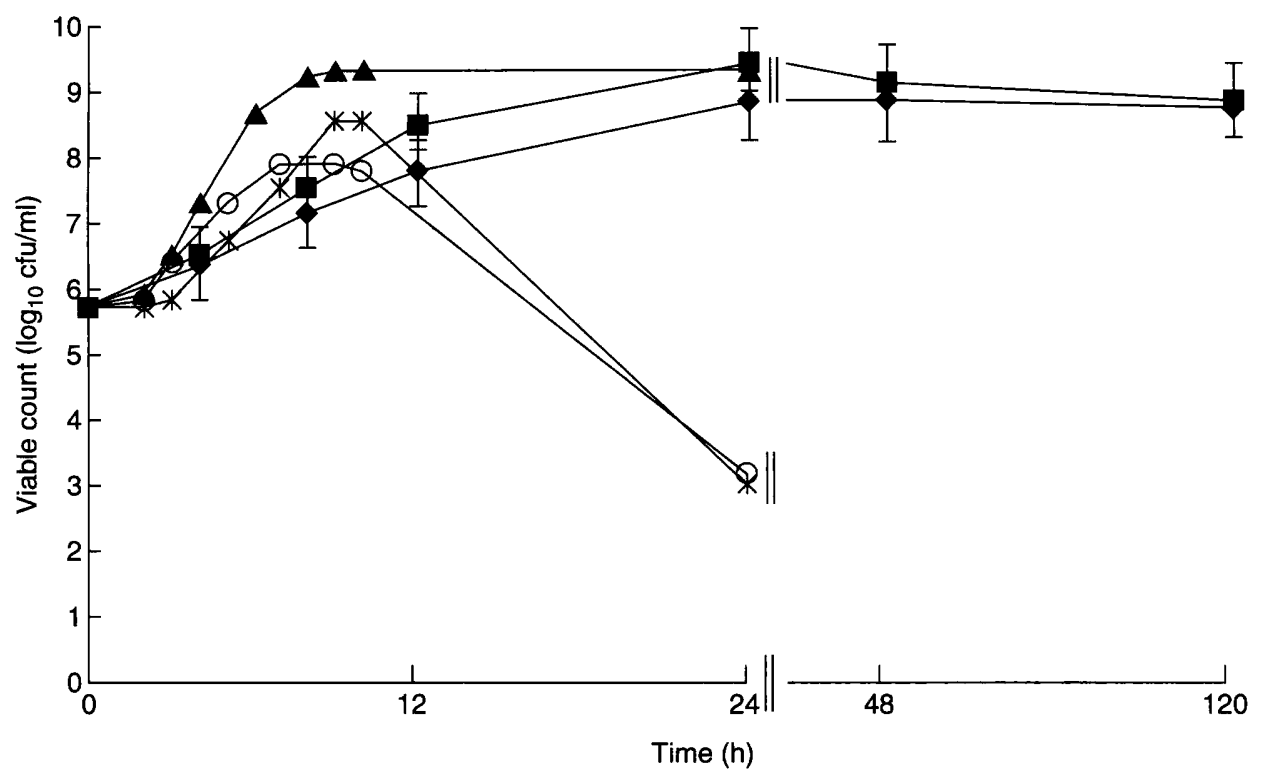

Fig. 1. Growth of $P$. mirabilis strain Pr 990 in SOC in mice $(\bullet)$, in IPC in rats (ם), in BHIB (A) and in human (*) and mouse (O) urine. Cultures in BHIB and in human and mouse urine were incubated statically at $37^{\circ} \mathrm{C}$. Growth was monitored by plate counts on NA. In the SOC assay, each point represents the mean and SD of four samples from different mice, taken at the same time. In the IPC assay, each point represents the mean and SD of samples from three different rats, taken at the same time. Scale was reduced to $1 / 7$ for period $24-120 \mathrm{~h}$.

SOC, a doubling time of 106 min was determined between 4 and $12 \mathrm{~h}$. No spread of bacteria from the chambers was found, as demonstrated by negative blood cultures. At $24 \mathrm{~h}$ after infection, the area surrounding the chamber was hard and the concentration of inflammatory cells recovered from the fluid within the chamber had increased 100 -fold (results not shown). At this time, the viable count in both models was $10^{8}-10^{9} \mathrm{cfu} / \mathrm{ml}$ and this persisted for 5 days in both models. In the SOC model, it persisted for 3-4 weeks, when almost all the chambers were rejected.

\section{Cellular differentiation}

The ratios between filamentous and vegetative cells of Pr 990 grown in BHIB, human or mouse urine are shown in Table 1. Long filamentous cells (Fig. 2a) were

Table 1. The ratio between filamentous and vegetative cells of $P$. mirabilis strain $\operatorname{Pr} 990$ when cultured in vivo in different conditions

\begin{tabular}{lccc}
\hline Time $(\mathrm{h})$ & BHIB & Human urine & Mouse urine \\
\hline 0 & 0 & 0 & 0 \\
2 & 0 & 0 & 0 \\
4 & $1: 56$ & $1: 985$ & $1: 8$ \\
6 & $1: 41$ & $1: 95$ & $1: 14$ \\
8 & $1: 101$ & $1: 300$ & $1: 71$ \\
10 & $1: 132$ & $1: 310$ & $1: 73$ \\
24 & $1: 78$ & $1: 236$ & 1.49
\end{tabular}

The ratio of vegetative and filamentous cells was assessed by light microscopy of methylene blue-stained smears: 0 , absence of filamentous cells (only vegetative cells could be seen). The ratio between long filamentous swarmer cells and short vegetative cells was calculated after counting and classifying all cells from 40 randomly chosen fields in duplicate preparations.
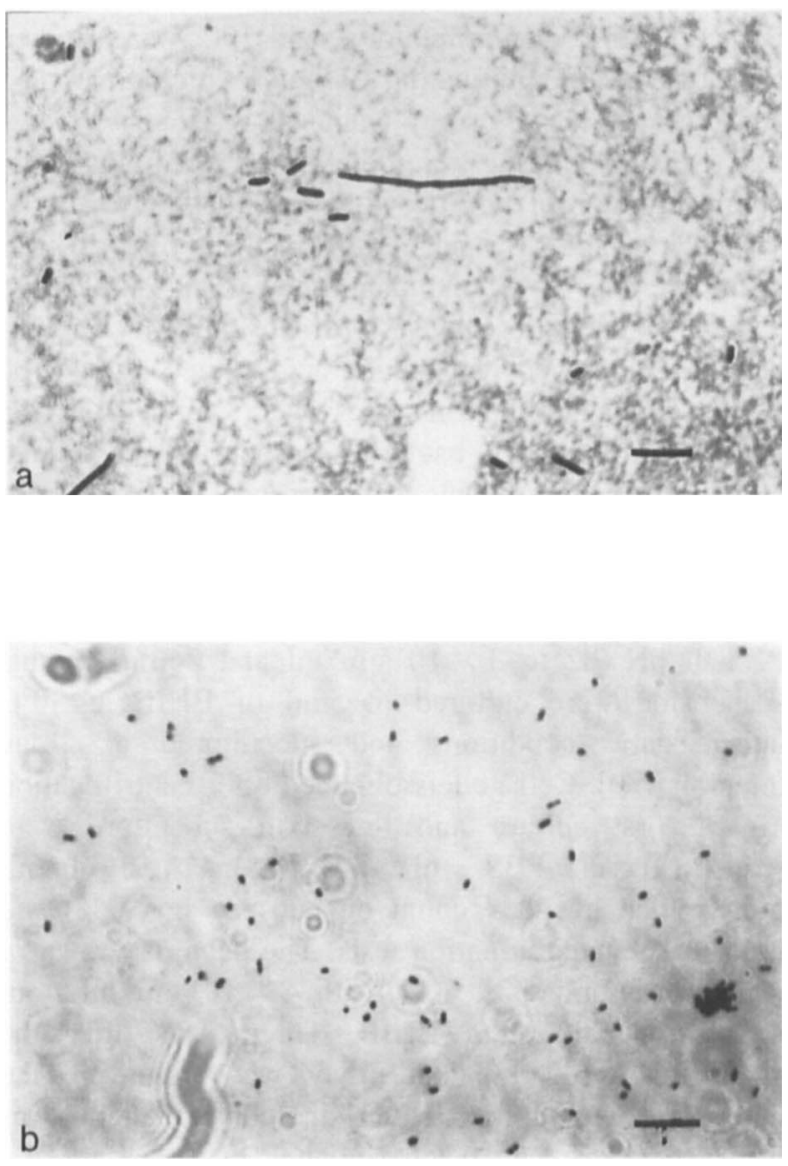

Fig. 2. The morphology of $P$ mirabilis strain $\operatorname{Pr} 990$. Smears were fixed and stained as described in Materials and methods. a, Grown in vitro in human urine; filamentous and vegetative cells can be seen; bar, $10 \mu \mathrm{m}$. b, Grown in vivo in rat IPC; only very short vegetative cells were seen; bar, $5 \mu \mathrm{m}$. 
seen in all cultures and the ratio of filamentous to vegetative cells increased by $4-6 \mathrm{~h}$, then decreased and later rose again by $24 \mathrm{~h}$. In the urine cultures, morphological changes in bacteria were observed after 16$18 \mathrm{~h}$ (results not shown) probably due to the high $\mathrm{pH}$ (9-9.2) generated by the presence of ammonia as a result of $P$. mirabilis urease activity on urea. However, no filamentous cells were seen at any time in either the IPC or the SOC in-vivo models. Moreover, the vegetative cells were much smaller than those seen in the in-vitro cultures (Fig. 2b). Although bacteria were in close contact with phagocytic cells, no bacteria were seen inside them in SOC in mice.

Within $1 \mathrm{~h}$ of infection, urine smears from transurethrally infected mice showed an increase in the ratio of filamentous to vegetative cells in every case, compared with the ratio of the initial inoculum (Table 2). Filamentous cells were not seen after $3 \mathrm{~h}$ in two of the four infected mice. In the other two, filamentous cells were present in the urine smears at $5 \mathrm{~h}$ after infection, but in lower proportions than in the original inoculum. In all mice, only short vegetative cells could be detected at $7 \mathrm{~h}$ after infection. No filamentous cells but only vegetative cells were seen in kidney homogenates prepared 7 days after infection.

\section{Haemagglutination}

The haemagglutination titres of bacteria grown in BHIB for both fresh and tanned erythrocytes increased with subculture (Table 3). However, bacteria recovered from IPCs and used at the same concentration as bacteria from BHIB did not show haemagglutination with either fresh or tanned erythrocytes (Table 3).

\section{Resistance to normal serum}

Strain Pr 990 showed a different level of resistance to normal rat serum when grown in vitro rather than in vivo (Table 4). Bacteria recovered from IPC from rats 2 days after implantation showed a significantly higher level of resistance to normal rat serum than bacteria grown overnight in BHIB $(p<0.05)$.

Table 2. Persistence of $P$. mirabilis strain $\operatorname{Pr} 990$ filamentous cells in the urinary tract of inoculated mice

\begin{tabular}{lcccc}
\hline & \multicolumn{4}{c}{ Ratio of filamentous to vegetative cells } \\
\cline { 2 - 5 } Time (h) after & Mouse 1 & Mouse 2 & Mouse 3 & Mouse 4 \\
\hline 0 & $1: 55$ & $1: 55$ & $1: 55$ & $1: 55$ \\
1 & $1: 6$ & $1: 48$ & $1: 5$ & $1: 32$ \\
2 & $1: 12$ & $1: 82$ & $1: 6$ & $1: 53$ \\
3 & $1: 30$ & $1: 80$ & $1: 20$ & $1: 73$ \\
5 & 0 & 0 & $1: 80$ & $1: 198$ \\
7 & 0 & 0 & 0 & 0 \\
24 & 0 & 0 & 0 & 0 \\
48 & 0 & 0 & 0 & 0 \\
\hline
\end{tabular}

The ratio at time $0 \mathrm{~h}$ is that of the inoculum.
Table 3. Haemagglutination of $P$. mirabilis strain Pr 990 grown in vitro and in vivo

\begin{tabular}{|c|c|c|c|}
\hline \multirow[b]{2}{*}{ Erythrocytes } & \multicolumn{3}{|c|}{ Haemagglutination titre } \\
\hline & $\begin{array}{l}\text { Sub 1* } \\
\text { (BHIB) }\end{array}$ & $\begin{array}{l}\text { Sub } 6^{\dagger} \\
\text { (BHIB) }\end{array}$ & $\begin{array}{c}\text { IPC } \\
\text { (rats) }\end{array}$ \\
\hline \multicolumn{4}{|l|}{$\overline{\text { Fresh }^{\ddagger}}$} \\
\hline Human & 4 & 32 & 0 \\
\hline Chicken & 16 & 128 & 0 \\
\hline Tanned $^{\S}$ human & 8 & 64 & 0 \\
\hline
\end{tabular}

Haemagglutination titre was defined as the highest dilution in which erythrocyte clumps could be seen. The haemagglutination experiments were repeated and similar results were observed.

${ }^{*}$ Sub 1 was a 3-day-old culture in $5 \mathrm{ml}$ of $\mathrm{BHIB}$ at $30^{\circ} \mathrm{C}$ in static conditions.

${ }^{\dagger}$ Sub 6 was the sixth subculture made at 3-day intervals.

${ }^{\ddagger}$ Fresh erythrocytes were used to assess mannose-resistant/Proteuslike fimbriae.

${ }^{\S}$ Tanned erythrocytes were used to assess mannose-resistant/Klebsiella-like fimbriae.

Table 4. The resistance of $P$. mirabilis strain $\operatorname{Pr} 990$ grown in vitro (BHIB) or in vivo (IPC) to the bactericidal effect of normal serum

\begin{tabular}{lcc}
\hline & \multicolumn{2}{c}{ Percentage cell death } \\
\cline { 2 - 3 } Serum dilution & in vivo & in vitro \\
\hline 2 & 42 & 94 \\
4 & 30 & 88 \\
8 & 6 & 47 \\
16 & 0 & 23 \\
32 & 0 & 8 \\
64 & 0 & 0 \\
\hline
\end{tabular}

The difference in cell death between cells grown in vivo and in vitro was significant $(\mathrm{p}<0.05)$. Serum was obtained by cardiac puncture from a healthy rat bled immediately before the assay. Bacterial suspensions were prepared from an overnight culture in BHIB and from an IPC 2 days after implantation. In-vitro and in-vivo assays were done simultaneously and colony counts were made on duplicate NA plates after incubation for $48 \mathrm{~h}$ at $37^{\circ} \mathrm{C}$. A similar significant difference was observed in a repeat experiment.

\section{Haemolysin assay}

Notably different levels of haemolysin activity were detected when strain $\operatorname{Pr} 990$ was grown in different environments (Table 5). Bacteria showed high haemolytic activity during early exponential growth in BHIB.

Table 5. The haemolytic activity of $P$. mirabilis strain Pr 990 when grown in vitro and in vivo

\begin{tabular}{lcccc}
\hline Time (h) & \multicolumn{4}{c}{ Haemolytic titre after growth in } \\
\cline { 2 - 5 } after \\
infection & BHIB & Human urine & Mouse urine & IPC (rat) \\
\hline 3 & 4 & 0 & 0 & ND \\
4 & ND & ND & ND & 0 \\
5 & 32 & 0 & 0 & ND \\
7 & 16 & 0 & 1 & ND \\
8 & ND & ND & ND & 8 \\
9 & 2 & 0 & 0 & ND \\
12 & ND & ND & ND & 2 \\
24 & 0 & 0 & 0 & 0 \\
\hline
\end{tabular}

Haemolytic titre was the last dilution in which no visible rbc pellet was observed; $0.1 \mathrm{ml}$ of two-fold dilutions of bacterial suspensions was mixed with $0.05 \mathrm{ml}$ of a $3 \%$ suspension of sheep rbc and incubated at $37^{\circ} \mathrm{C}$ for $1 \mathrm{~h}$ [29]. ND, not done. The experiment was repeated and similar haemolytic titres were observed. 
Haemolytic activity later decreased and was absent at the end of the exponential phase. Almost no haemolytic activity was detected when strain Pr 990 was grown in mouse urine and none was seen in human urine. When strain Pr 990 was grown in IPC, significant haemolysin titres were detected by $8 \mathrm{~h}$ after chamber implantation. No haemolytic activity was detected at $24 \mathrm{~h}$.

\section{Discussion}

Different models have been developed to assess $P$. mirabilis behaviour in vivo and expression of virulence factors such as fimbriae, serum resistance, haemolysin activity and swarmer cell differentiation. The commonest infection model for studying uropathogenic $P$. mirabilis virulence factors is ascending UTI in mice [14]; therefore growth in mouse and human urine was studied. Urine may prevent bacterial growth, not only by its continuous flow, but also because of its osmolarity, urea concentration and iron deficiency properties [31]. The ability shown by $P$. mirabilis to grow quickly in human or mouse urine is advantageous for the colonisation of the urinary tract. Thus the virulence factors expressed by bacteria growing in these media could give valuable information on the mechanisms of initiation of UTI.

In the IPC and SOC in-vivo models, a slower growth rate was seen than in in-vitro assays. Although the sampling could not be so frequent as in in-vitro growth studies, a more extended exponential phase was noticed and a doubling time between 4 and $12 \mathrm{~h}$ after the chambers were implanted or inoculated was calculated. In the IPC model, this was $72 \mathrm{~min}$. This result agrees with much of the available experimental evidence that indicates longer bacterial doubling times in vivo, as was reported for Ps. aeruginosa inoculated into the kidneys of mice, Salmonella typhimurium in mice spleen and Vibrio cholerae growing in the small intestine of infant mice [32]. Although the slower growth rate observed in vivo may be a consequence of nutrient limitation (this would also explain the small size of the recovered bacteria), $P$. mirabilis grew well and survived under these conditions. This suggests that outer-membrane proteins as potential specialised virulence factors for survival may play an important role in natural infections.

The SOC model allowed studies of bacterial infectivity and survival in the presence of an inflammatory response [16], when bacteria must survive and proliferate in the presence of phagocytic cells, antibodies and complement. $P$. mirabilis persisted and multiplied in these chambers without spreading to the blood and showed a 100 -fold increase in the number of cells after $24 \mathrm{~h}$. A doubling time of $106 \mathrm{~min}$, longer than in IPC, was detected. Surprisingly, no change in the viable count was observed over 3-4 weeks, until the chambers were rejected. This was different behaviour from that described for $H$. ducreyi inoculated into $\mathrm{SOC}$ in mice, where a 100 -fold increase after $24 \mathrm{~h}$ was followed by a sharp decline over the next few days [17], but similar to that observed with serum resistant variants of a $N$. gonorrhoeae strain [16] in guinea-pig subcutaneous chambers. This result also showed the ability of $P$. mirabilis to survive in vivo in the presence of an inflammatory response. This ability may reflect the expression of resistance to the bactericidal action of normal serum.

Survival inside phagocytic cells has been considered as a possible mechanism of bacterial pathogenicity [16]. However, no intracellular $P$. mirabilis cells were seen in SOC fluid by light microscopy. This result is similar to that reported by others [16] in guinea-pigs infected with serum-resistant variants of a $N$. gonorrhoeae strain. On the other hand, no bacterial clearance was seen inside the chambers during the course of infection. This model could provide an interesting tool to study bacteria-inflammatory cell interactions in vivo.

This study also assessed the in-vivo expression of certain virulence factors, a fundamental step in pathogenicity studies. A common characteristic of $P$. mirabilis is its co-ordinate multicellular behaviour, known as swarming, that occurs when cells grow on solid rich media or on viscous surfaces $[28,33]$ or, for some strains, in liquid media [34]. Some reports indicate that swarming motility dependent on flagella occurs in vivo and that it favours the infection of the urinary tract $[11,35]$. However, other reports showed that swarming cells divided into short vegetative cells once they reached the surface of cultured epithelial cells and that they were much less able to invade epithelial cells than short rods $[36,37]$. In all the invitro assays in the present study, the bacteria were able to differentiate into multiflagellate filamentous cells, as assessed by light and electron microscopy. Ascending UTI experiments in mice showed that within $6 \mathrm{~h}$ of trans-urethral inoculation with a bacterial suspension containing a large amount of swarmer cells, a large proportion of these cells was seen in urine smears. Seven hours after inoculation, only short cells were seen in urine, suggesting that swarmer cells could be removed more easily from the urinary tract, probably because of urinary flow and steric hindrance to adhesion caused by the large number of flagella. It is also possible that inoculated filamentous cells divided into vegetative cells in vivo after contacting the epithelial cells surface, as was seen previously in in-vitro assays [36]. Filamentous cells were not seen in kidneys 7 days after inoculation, which is consistent with previous findings. Moreover, filamentous cells were not found in either of the in-vivo chamber models at any stage of the experiment. Recently, Zhao et al. [38] showed that swarmer cells of $P$. mirabilis could not be found in the kidneys of infected mice in an assay using a green fluorescent protein to assess 
urease gene expression. However, the possibility that these cells had invaded kidney cells where the urea concentration was too low to induce the fusion protein was not excluded. The results of the present study suggest that swarming differentiation may not be always present or necessary in $P$. mirabilis UTI.

Adhesion mechanisms have been recognised as a relevant factor for the development of UTI [29], although the exact role of the different types of fimbriae in $P$. mirabilis pathogenicity is still under study. The IPC in-vivo model, although able to provide an excellent medium for growth, did not permit the expression of haemagglutination fimbriae. It has been proposed that fimbrial expression is strongly dependent on environmental characteristics and on the ability to grow rapidly [39]. Thus, it appears that the chamber environment is not appropriate for fimbriation. It is possible that on-off phase variation of $M R / P$ fimbrial expression recently described [40] for $P$. mirabilis may be present (and similar events could occur for $\mathrm{MR} / \mathrm{K}$ ), although the switch was always in the 'on' position in urinary tract infective bacteria [40].

Although resistance to normal serum may be important in the pathogenesis of $P$. mirabilis [13], there are no reports of the expression of this virulence factor in vivo. The rat IPC model provided a useful tool to determine the acquisition of resistance to normal serum by $P$. mirabilis in vivo. This virulence factor may contribute to invasiveness and the occurrence of bactaeremia described in cases of acute pyelonephritis involving $P$. mirabilis [41].

Haemolysin has been considered to be an important potential virulence factor by some authors [4], while others could not observe significant differences in virulence after isogenic mutants were assessed in the ascending UTI model in mice [42]. Mobley et al. [24] consider that the effect of haemolysin in the kidney may be subtle and difficult to measure in the ascending UTI mouse model. The results of the present study suggest that haemolysin was not essential during the early infection because it was not detected when bacteria grew in human urine and only extremely low titres were found in mouse urine. However, detection in vivo of haemolysin activity in the IPC model may indicate that this factor is important at later stages of infection [42].

This work was partially supported by Project 056 BID-CONICYTUruguay and by Project $\mathrm{CI}^{*}$-CT $94-0001$ from the Commission of the European Communities. We thank Monica Brauer and Anabel Fernández for their help in electron microscopy studies and D. Maskell for his critical reading of the manuscript.

\section{References}

1. Stamm WE, Martin SM, Bennett JV. Epidemiology of nosocomial infections due to Gram-negative bacilli: aspects relevant to development and use of vaccines. $J$ Infect Dis 1977; 136 Suppl: S151-S160.

2. Senior BW. The special affinity of particular types of Proteus mirabilis for the urinary tract. $J$ Med Microbiol 1979; 12: 1-8.

3. Mobley HLT, Hausinger RP. Microbial ureases: significance, regulation, and molecular characterization. Microbiol Rev 1989; 53: $85-108$.

4. Peerbooms PGH, Verweij AMJJ, MacLaren DM. Vero cell invasiveness of Proteus mirabilis. Infect Immun 1984; 43: 1068-1071.

5. Allison C, Lai H-C, Hughes C. Co-ordinate expression of virulence genes during swarming-cell differentiation and population migration of Proteus mirabilis. Mol Microbiol 1992; 6: 1583-1591.

6. Loomes LM, Senior BW, Kerr MA. A proteolytic enzyme secreted by Proteus mirabilis degrades immunoglobulins of the immunoglobulin A1 (IgA1), IgA2, and IgG isotypes. Infect Immun 1990; 58: 1979-1985.

7. Moayeri N, Collins CM, O'Hanley P. Efficacy of a Proteus mirabilis outer membrane protein vaccine in preventing experimental pyelonephritis in a BALB/c mouse model. Infect Immun 1991; 59: 3778-3786.

8. Welch RA. Identification of two different hemolysin determinants in uropathogenic Proteus isolates. Infect Immun 1987; 55: $2183-2190$.

9. Bahrani FK, Johnson DE, Robbins D, Mobley HLT. Proteus mirabilis flagella and $\mathrm{MR} / \mathrm{P}$ fimbriae: isolation, purification, $\mathrm{N}-$ terminal analysis, and serum antibody response following experimental urinary tract infection. Infect Immun 1991; 59: 3574-3580.

10. Wray SK, Hull SI, Cook JRG, Barrish J, Hull RA. Identification and characterization of a urinary cell adhesin from a uropathogenic isolate of Proteus mirabilis. Infect Immun 1986; 54: 43-49.

11. Pazin GJ, Braude AI. Immobilizing antibodies in urine. II. Prevention of ascending spread of Proteus mirabilis. Invest Urol 1974; 12: 129-133.

12. Allison C, Coleman N, Jones PL, Hughes C. Ability of Proteus mirabilis to invade human urothelial cells is coupled to motility and swarming differentiation. Infect Immun 1992; 60: $4740-4746$

13. Larsson P, Olling S. $O$ antigen distribution and sensitivity to the bactericidal effect of normal human serum of Proteus strains from clinical specimens. Med Microbiol Immunol 1977; 163: $77-82$.

14. Hagberg L, Engberg Y, Freter R, Lane J, Olling S, SvanborgEdén C. Ascending, unobstructed urinary tract infection in mice caused by pyelonephritogenic Escherichia coli of human origin. Infect Immun 1983; 40: 273-283.

15. Legnani-Fajardo $C$, Zunino P, Algorta G, Laborde HF. Antigenic and immunogenic activity of flagella and fimbriae preparations from uropathogenic Proteus mirabilis. Can $J$ Microbiol 1991; 37: 325-328.

16. Demarco de Hormaeche $R$, Macpherson A, Bowe F, Hormaeche CE. Alteration of the LPS determine virulence of Neisseria gonorrhoeae in guinea-pig subcutaneous chambers. Microb Pathog 1991; 11: 159-170.

17. Trees DL, Arko RJ, Morse SA. Mouse subcutaneous chamber model for in vivo growth of Haemophilis ducreyi. Microb Pathog 1991; 11: 387-390.

18. Jonsson M, Elmros T, Bergström S. Subcutaneous implanted chambers in different mouse strains as an animal model to study genetic stability during infection with Lyme disease Borrelia. Microb Pathog 1995; 18: 109-114.

19. Quessy S, Dubreuil JD, Jacques M, Malouin F, Higgins R. Increase of capsular material thickness following in vivo growth of virulent Streptococcus suis serotype 2 strains. FEMS Microbiol Lett 1994; 115: 19-26.

20. Kelly NM, Bell A, Hancock REW. Surface characteristics of Pseudomonas aeruginosa grown in a chamber implant model in mice and rats. Infect Immun 1989; 57: 344-350.

21. Garduño RA, Thornton JC, Kay WW. Aeromonas salmonicida grown in vivo. Infect Immun 1993; 61: 3854-3862.

22. Arbuthnott JP, Arbuthnott ER, Arbuthnott ADJ, Pike WJ, Cockayne A. Investigation of microbial growth in vivo: evaluation of a novel in vivo chamber implant system. FEMS Microbiol Lett 1992; 100: 75-80.

23. Sareneva T, Holthöfer H, Korhonen TK. Tissue-binding affinity of Proteus mirabilis fimbriae in the human urinary tract. Infect 
Immun 1990; 58: 3330-3336.

24. Mobley HLT, Belas R, Lockatell V et al. Construction of a flagellum-negative mutant of Proteus mirabilis: effect on internalization by human renal epithelial cells and virulence in a mouse model of ascending urinary tract infection. Infect Immun 1996; 64: 5332-5340.

25. Legnani-Fajardo C, Zunino P, Piccini C, Allen A, Maskell D. Defined mutants of Proteus mirabilis lacking flagella cause ascending urinary tract infection in mice. Microb Pathog 1996; 21: $395-405$.

26. Krieg NZ, Gerhardt P. Solid culture. In: Manual of methods for general microbiology. Washington, DC, American Society for Microbiology, 1984: 143-150.

27. Belas R, Erskine D, Flaherty D. Proteus mirabilis mutants defective in swarmer cell differentiation and multicellular behavior. $J$ Bacteriol 1991; 173: 6279-6288.

28. Mobley HLT, Belas R. Swarming and pathogenicity of Proteus mirabilis in the urinary tract. Trends Microbiol 1995; 3: 280 284.

29. Mobley HLT, Chippendale GR. Hemagglutinin, urease, and hemolysin production by Proteus mirabilis from clinical sources. J Infect Dis 1990; 161: 525-530.

30. Adegbola RA, Old DC, Senior BW. The adhesins and fimbriae of Proteus mirabilis strains associated with high and low affinity for the urinary tract. $J$ Med Microbiol 1983; 16: 427431.

31. Robledo JA, Serrano A, Domingue GJ. Outer membrane proteins of $\mathrm{E}$. coli in the host-pathogen interaction in urinary tract infection. $J$ Urol 1990; 143: 386-391.

32. Smith H. Pathogenicity and the microbe in vivo. The 1989 Fred Griffith Review Lecture. J Gen Microbiol 1990; 136: 377-383.

33. Williams FD, Schwarzhoff RH. Nature of the swarming phenomenon in Proteus. Annu Rev Microbiol 1978; 32: 101122.

34. Dick H, Murray RGE, Walmsley S. Swarmer cell differentiation of Proteus mirabilis in fluid media. Can J Microbiol 1985; 31: $1041-1050$.

35. Allison C, Emödy L, Coleman N, Hughes C. The role of swarm cell differentiation and multicellular migration in the uropathogenicity of Proteus mirabilis. J Infect Dis 1994; 169: $155-158$.

36. Chippendale GR, Warren JW, Trifillis AL, Mobley HLT. Internalization of Proteus mirabilis by human renal epithelial cells. Infect Immun 1994; 62: 3115-3121.

37. Oelschlaeger TA, Tall BD. Uptake pathways of clinical isolates of Proteus mirabilis into human epithelial cell lines. Microb Pathog 1996; 21: 1-16.

38. Zhao H, Thompson RB, Lockatell V, Johnson DE, Mobley HLT. Use of green fluorescent protein to assess urease gene expression by uropathogenic Proteus mirabilis during experimental ascending urinary tract infection. Infect Immun 1998; 66: $330-335$.

39. Williams P. Role of the cell envelope in bacterial adaptation to growth in vivo in infections. Biochimie 1988; 70: 987-1011.

40. Zhao $\mathrm{H}, \mathrm{Li} \mathrm{X}$, Johnson DE, Blomfield $\mathrm{Y}$, Mobley HLT, In vivo phase variation of MR/P fimbrial gene expression in Proteus mirabilis infecting the urinary tract. Mol Microbiol 1997; 23: 1009-1019.

41. Warren JW, Damron D, Tenney JH, Hoopes JM, Deforge B, Muncie HL. Fever, bacteremia, and death as complications of bacteriuria in women with long-term catheters. $J$ Infect Dis 1987: 155: $1151-1158$.

42. Swihart KG, Welch RA. The HpmA haemolysin is more common than HlyA among Proteus isolates. Infect Immun 1990; 58: $1853-1860$. 